\title{
GIÁ TR!̣ CỦA ĐƯờng MỞ NGỰC TỐI THIỂU TRONG PHẪU THUẬT ĐIỀU TR! UNG THU' PHỔI KHÔNG TẾ BÀO NHỎ TẠI BỆNH VIỆN HŨUU NGHỊ VIỆT ĐỨC
}

Bùi Văn Bìn**, Phạm Hũu Lu**

\section{TÓM TẮT}

93 bệnh nhân được chọn vào mẫu nghiên cứu với tỉ lệ nam/nữ $=1,7$ và tuổi trung bình là $56,87 \pm 10,9$ (từ 15 đến 76 tuổi). Thời gian phẫu thuật trungbình $155,10 \pm 38,5$ phút, có $3 \mathrm{BN}$ phải truyền máu trong mổ $(3,23 \%)$, thời gian dẫn lưu

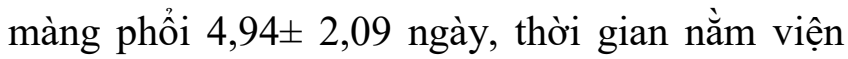

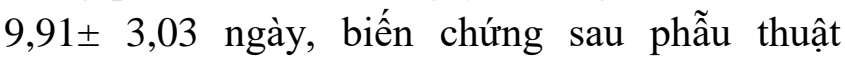
chiếm 10,8\%. Chức năng khớp vai bình thường và gần như bình thường lần lượt là $39,1 \%$ và $52,4 \%, 100 \% \mathrm{BN}$ hài lòng và rất hài lòng về thẩm mỹ của vết mổ sau phẫu thuật. Đường mổ ngực tối thiểu là đường mổ khả thi, hiệu quả, an toàn trong phẫu thuật điều trị ung thư phổi không tế bào nhỏ, khắc phục một số hạn chế của đường mổ ngực sau - bên kinh điển.

Tù khóa: Ung thu biểu mô không tế bào nhỏ, đường mở ngục tối thiểu

\section{SUMMARY}

\section{EVALUATION OF EARLY RESULTS OF} SURGICAL TREATMENT NON-SMALL

CELL LUNG CANCER BY MUSCLE-

\section{SPARING MINITHORACOTOMY IN VIET}

\section{DUC UNIVERSITY HOSPITAL}

93 patients were selected with a male/female ratio of 1.7 and an average age of $56.87 \pm 10.9$ years (15 to 76 years). The average time of operation was $155.10 \pm 38.5$ minutes, three patients had transfusions $(3.23 \%)$, The drainage time was $4.94 \pm 2.09$ days, The hospitalization time was $9,91 \pm 3.03$ days, postoperative complications accounted for $10.8 \%$. Good and normal shoulder function were $39.1 \%$ and $52.4 \%$ respectively, $100 \%$ of patients were satisfied and very satisfied with the aesthetics of postoperative surgery. Conclusion: A muscle - sparing minithoracotomy is a viable, effective, safe procedure for the treatment of small non-small cell lung cancer, and to overcome some of the limitations of the posterior-lateral thoracotomy.

Keyword: $\quad$ NSLC, Muscle-sparing minithoracotomy

\section{I. ĐẶT VẤN ĐỀ:}

Ung thư phổi không tế bào nhỏ (UTPKTBN) là loại ung thư biểu mô chiếm trên $85 \%$ tổng số bệnh nhân mắc ung thư phổi và là một trong những nguyên nhân gây tử vong hàng đầu tại Việt Nam cũng như trên thế giới. Cho tới nay, phẫu thuật vẫn là phương pháp điều trị hiệu quả nhất đối với giai đoạn bệnh còn khu trú tại chỗ và xu hướng của các phương pháp phẫu thuật hiện nay là ngày càng ít xâm lấn.

Phẫu thuật bằng đường mở ngực tối thiểu (ĐMNTT) là phương pháp phẫu thuật ít xâm lấn có độ dài đường rạch da nhỏ $(5-8 \mathrm{~cm})$, hạn chế tối đa sự cắt cơ thành ngực (chỉ cắt cơ liên sườn), các xương sườn được banh rộng ra cho phép thực hiện hầu hết các kĩ thuật trong phẫu thuật lồng ngực. Phương pháp nàycó nhiều ưu điểm, hiệu quả cao và mang lại nhiều lợi ích cho bệnh nhânnhưng không phải là không có hạn chế. Bài báo này đánh giá kết quả sớm phẫu thuật điều trị ung thư phổi không tế bào nhỏ bằng đường mở ngực tối thiểu tại Bệnh viện Hữu Nghị Việt Đức.

\footnotetext{
* Bác sỹ nội trú Ngoại lồng ngục - Truờng đại học y Hà Nội **Khoa phẫu thuật Tim mạch và Lồng ngục - Bệnh viện Việt Đức Ngưòi chịu trách nhiệm khoa học: TS. Phạm Hũu Lu

Ngày nhận bài: 01/05/2018 - Ngày Cho Phép Đăng: 20/05/2018

Phản Biện Khoa học: GS.TS. Bùi Đúc Phú PGS.TS. Đặng Ngọc Hùng
} 


\section{II. ĐỐI TƯợNG VÀ PHƯƠNG PHÁP NGHIÊN CÚ'U}

2.1.Đối tượng nghiên cứu: Gồm 93 bệnh nhân $(\mathrm{BN})$ được phẫu thuật điều trị UTPKTBN bằng ĐMNTT tại khoa phẫu thuật tim mạch- lồng ngực Bệnh viện Hữu Nghị Việt Đức trong thời gian 24 tháng (từ $1 / 2015$ đến 12/2016).

\subsection{Phương pháp nghiên cứu: Nghiên} cứu mô tả hồi cứu.

Các tham số - biến số nghiên cưu: Đặc điểm lâm sàng: tuổi, giới, triệu chứng lâm sàng; Cận lâm sàng: vị trí, kích thước u, kết quả giải phẫu bệnh; Kết quả trong mổ: thời gian phẫu thuật, cách thức phẫu thuật, nạo vét hạch, lượng máu truyền; Kết quả sớm sau mổ: biến chứng sớm sau phẫu thuật, thời gian điều trị sau phẫu thuật, mức độ đau,chức năng vận động khớp vai và mức độ hài lòng về thẩm mỹ vết mổ.

Quy trình phẫu thuật:

- $\quad$ BN được gây mê NKQ thông khí chọn lọc một phổi, tư thế nằm nghiêng $90^{\circ}$, kê gối dưới lưng để mở rộng khoang liên sườn, treo tay, chân dưới gấp, chân trên thẳng và được cố định bằng dây đai với bàn mổ.
- Phẫu thuật viên sử dụng đèn đầu đứng phía trước (phía bụng) bệnh nhân. Phụ phẫu thuật đứng phía sau (phía lưng) bệnh nhân.

- Kỹ thuật: Rạch da 5-8cm đường ngực bên từ đường nách trước đến đường nách sau khoang liên sườn IV hoặc V. Phẫu tích bó cơ lưng rộng theo chiều dọc rồi kéo ra phía sau bộc lộ cơ răng trước, phẫu tích bó cuối cùng của cơ răng trước rồi kéo ra trước. Cắt qua cơ gian sườn để vào khoang màng phổi. Sử dụng một banh ngực nhỏ làm rộng khoang liên sườn, có thể dùng banh ngực nhỏ thứ hai đặt vuông góc với chiếc thứ nhất để mở rộng trường quan sát. Bộc lộ $\mathrm{TM}, \mathrm{DM}, \mathrm{PQ}$ rồi cắt như trong phẫu thuật kinh điển và nạo vét hạch. Đặt dẫn lưu, trả các cơ lưng rộng và cơ răng trước về vị trí cũ, khâu đóng vết mổ.

Sau mổ đánh giá về mức độ đau, các biến chứng, thời gian phục hồi và mức độ hài lòng của $\mathrm{BN}$ về vết mồ.
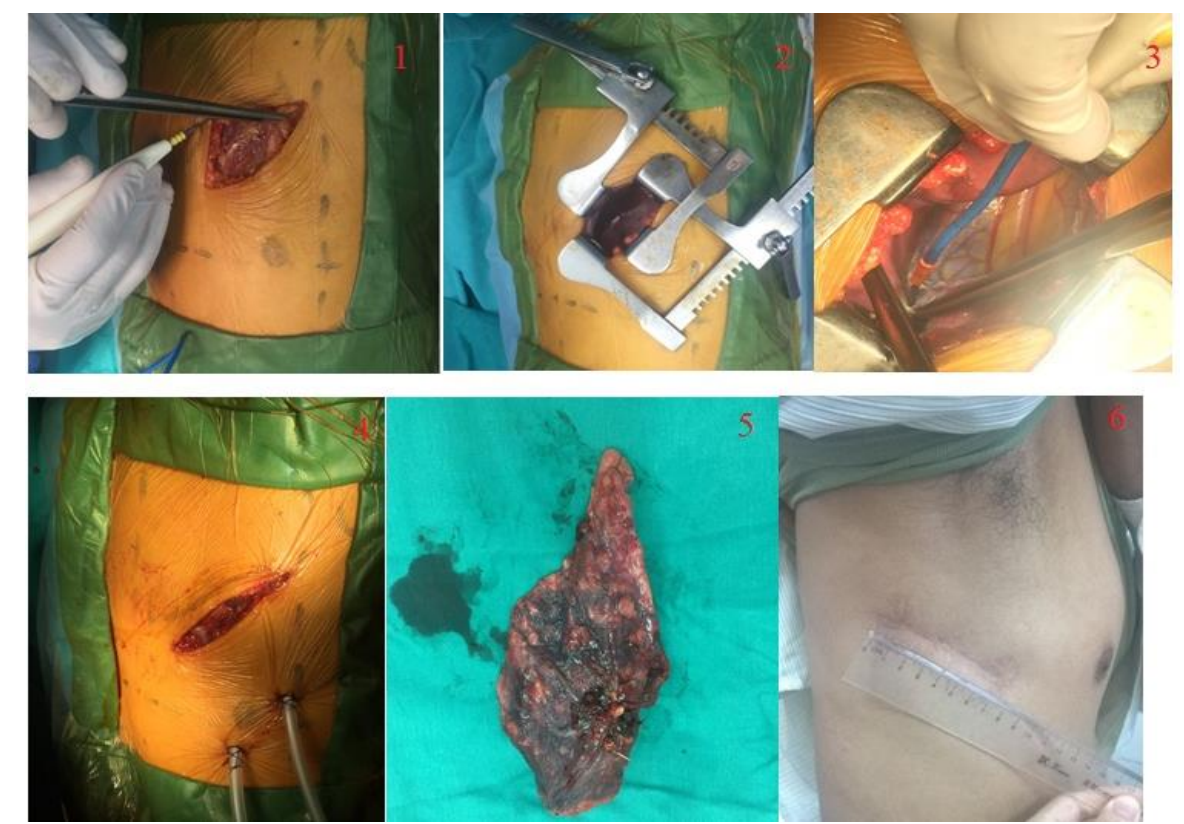

Hình 1. Phẫu tích co lung rộng; Hình 2. Mở rộng khoang liên suoòn bằng 2 banh ngục nhỏ; Hình 3. Phẫu truờng qua đường mở ngục tối thiểu; Hình 4. Đóng ngục trả lại vị trí các co thành ngụcc; Hình 5. Thùy phổi được cắt bỏ; Hình 6. Chiều dài sẹo mổ

Xư lý số liệu: Thu thập và xử lý số liệu bằng phần mềm SPSS 16.0 


\section{KẾT QUẢ NGHIÊN CỨU}

3.1.Đặc điểm bệnh nhân: Tuổi trung bình: $56,87 \pm 10,9$, từ 15 đến 76 tuổi; Tỉ lệ nam/nữ là $59 / 34=1,7$; Tiền sử hút thuốc lá, thuốc lào: $51,3 \%$; Triệu chứng lâm sàng thường gặp là đau, tức ngực và ho kéo dài chiếm $48,4 \%$ và $41,9 \%$.
3.2. Đặc điểm phẫu thuật: Thời gian phẫu thuật trung bình: $155,10 \pm 38,5$ phút, ngắn nhất là 85 phút và dài nhất là 310 phút. Có $3 / 93 \mathrm{BN}$ $(3,23 \%)$ phải truyền máu trong mổ với số lượng trung bình $833 \mathrm{ml}$.

Cách thức phẫu thuật (n=93):

\begin{tabular}{lcc}
\hline Phẫu thuật & n & $\%$ \\
\hline Cắt 1 thùy phổi & 75 & 80,6 \\
\hline Cắt 2 thùy phổi & 13 & 14,0 \\
\hline Cắt 1 thùy phồi +1 phần thùy phổi & 4 & 4,3 \\
\hline Cắt 1 phối & 1 & 1,1 \\
\hline Tổng & 93 & 100 \\
\hline
\end{tabular}

3.3. Kết quả sớm sau phẫu thuật: Thời gian dẫn lưu màng phổi trung bình 4,94 2,09 ngày; Thời gian nằm viện trung bình là $9,91 \pm$ 3,03 ngày. Có 51/93 (54,8\%) BN sử dụng giảm đau ngoài màng cứng, tất cả các $\mathrm{BN}$ này chỉ phải dùng 1 loại thuốc giảm đau Paracetamol sau phẫu thuật. Chỉ $33 \% \mathrm{BN}$ phải dùng 2 loại là Paracetamol và Morphin. Biến chứng sau phẫu thuật chiếm $10,8 \%$, rò khí kéo dài có $7 \mathrm{BN}, 1$ trường hợp chảy máu sau mổ phải mổ lại và 2 trường hợp nhiễm trùng vết mổ. Chức năng khớp vai: Mức độ vận động khớp vai sau phẫu thuật bình thường và gần như bình thường là rất cao lần lượt là $39,1 \%$ và $52,4 \%$. Chỉ có 7 trường hợp vận động kém chiếm $8,5 \%$. 100\% $\mathrm{BN}$ hài lòng và rất hài lòng $(47,6 \%$ và $52,4 \%)$ về thẩm mỹ của vết mổ sau phẫu thuật.

\section{BÀN LUẬN:}

Trước những năm 1930, bác sĩ phẫu thuật lồng ngực thường thực hiện những phẫu thuật đơn giản trong lồng ngực. Sau đó, với sự ra đời phương pháp thông khí chọn lọc một phổi (1931) và ống NKQ 2 nòng (1949) mà bác sĩ phẫu thuật lồng ngực đã có thể cho ngừng một bên phổi và dễ dàng thực hiện các phẫu thuật trong lồng ngực. Cho đến nay phẫu thuật lồng ngực không ngừng phát triển, có thể thực hiện hầu hết các phẫu thuật trong lồng ngực đến các phẫu thuật phức tạp như ghép phổi[1]. Hơn nữa, những kỹ thuật mới với nhiều ưu điểm, hiệu quả cao đã được áp dụng trong đó phẫu thuật ít xâm lấn là một hướng phát triển đang được nhiều trung tâm trong và ngoài nước quan tâm, dần thay thế cho phương pháp mở ngực sau bên tiêu chuẩn gây tổn thương nhiều cơ thành ngực và biến chứng đáng kể sau mổ. Năm 1973, Noirclerc và cộng sự đã lần đầu tiên mổ tả đường mở ngực tối thiểu hạn chế cắt cơ và thấy giảm đáng kể các biến chứng so với mở ngực tiêu chuẩn. Lần lượt sau đó, Baeza $\mathrm{OR}$ và Foster $\mathrm{ED}$ (năm 1976); Bethencourt và Holmes (năm 1988) cũng báo cáo những ưu điểm của kĩ thuật mở ngực mới như giảm đau sau mổ, phục hồi chức năng khớp vai tốt và rút ngắn thời gian nằm viện[2],[3].

Trong nghiên cứu của chúng tôi, với đường rạch da nhỏ từ 5-8 cm chophép thực hiện kỹ thuật một cách thuận lợi mà không làm tăng nhiều thời gian phẫu thuật $(155,10 \pm 38,5$ phút). So với đường mở ngực sau - bên kinh điển, đường mở ngực hạn chế cắt cơ có thể mất nhiều thời gian hơn để mở ngực nhưng thời gian đóng ngực lại nhanh hơn, đỡ chảy máu hơn do không mất thời gian cầm máu, khâu lại cân cơ đã cắt. Thời gian thực tế phẫu thuật phụ thuộc vào từng phẫu thuật viên, đối với phầu thuật viên quen với trường mổ nhỏ thì thời gian phẫu thuật cũng không lâu hơn so với đường mổ kinh điển[4].

Benedetti đánh giá tình trạng đau ngực 1 tháng sau phẫu thuật chỉ ra rằng tổn thương thần kinh liên sườn là nguyên nhân dẫn đến đau kéo dài ở bệnh nhân sau mồ. Ông cũng nhận thấy 
rằng đường mở ngực sau - bên liên quan đến tổn thương thần kinh liên sườn nhiều hơn là đường mở ngực tách cơ. Nhiều nghiên cứu cũng chỉ ra rằng, nguyên nhân gây tổn thương thần kinh liên sườn ở bệnh nhân sau mổ lồng ngực thường do 2 lý do: Banh ngực chèn vào bó mạch thần kinh liên sườn trong quá trình mổ và động tác siết sườn (khâu giữa xương sườn trên và xương sườn dưới) với đường mổ nhỏ banh sườn ở mức tối thiểu và không siết sườn sau mổ có thể là lý do đường mổ hạn chế cắt cơ ít gây đau hơn [5].

Có nhiều nghiên cứu trên thế giới chứng minh chức năng khớp vai được phục hồi hoàn toàn và nhanh sau phẫu thuật với đường mở ngực tối thiểu [2],[3],[6],[7],[8],[9].... Tất cả các báo cáo đều cho rằng chức năng khớp vai, biên độ vận động và sức mạnh của cánh tay được phục hồi một cách ấn tượng sau phẫu thuật, cải thiện rõ rệt so với đường mở ngực sau - bên kinh điển. Ngoài ra đường mổ này cũng đảm bảo yếu tố thẩm mỹ khi gần như toàn bộ đường rạch da được cánh tay che phủ, $100 \% \mathrm{BN}$ trong nghiên cứu hài lòng và rất hài lòng về thẩm mỹ của vết mổ sau phẫu thuật. Sẹo mổ nhỏ và không có gờ 'sẹo xơ' hình thành khi khâu nối lại cơ đã cắt trong quá trình đóng như vết mổ truyền thống. Điều này có ý nghĩa đối với những bệnh nhân còn trẻ tuổi, yêu cầu thẩm mỹ cao, nâng cao chất lượng cuộc sống sau mổ.

Một ưu điểm nữa là chúng tôi chỉ ghi nhận 2 trường hợp bị nhiễm trùng vết mổ $(2,1 \%)$. Với đường mở ngực sau bên kinh điển, với việc cắt ngang các cơ thành ngực sau đó khâu đóng lại vết mổ không thể tránh khỏi việc thiểu dưỡng và hoại tử một phần cơ ngực tại đường mở, điều này dần đến tăng nguy cơ nhiễm trùng vết mổ.

Một lợi ích khác của đường mổ này là trong nhữngtrường hợp có biến chứng rò phế quản sau mổ. Cơ lưng rộng và cơ răng trước được dùng như một vậtliệu để đóng lỗ rò, điều này là khó thực hiện đối vớiđường mổ sau bên kinh điển [4].

\section{KẾT LUẬN:}

ường mổ ngực tối thiểu là đường mổ khả thi, hiệu quả, an toàn trong phẫu thuật điều trị ung thư phổi không tế bào nhỏ, khắc phục một số hạn chế của đường mổ ngực sau - bên kinh điển.

\section{TÀI LIẾU THAM KHẢO}

1. J. B. Brodsky và H. J. Lemmens (2007). The history of anesthesia for thoracic surgery. Minerva Anestesiol, 73(10), 513-524.

2. Daniel $M$ Bethencourt và $E$ Carmack Holmes (1988). Muscle-sparing posterolateral thoracotomy. The Annals of Thoracic Surgery, 45(3), 337-339.

3. M Ashour (1990). Modified muscle sparing posterolateral thoracotomy. Thorac, 45, 935-938.

4. K. Athanassiadi, S. Kakaris, N. Theakos và cộng sự (2007). Muscle-sparing versus posterolateral thoracotomy: a prospective study. Eur J Cardiothorac Surg, 31(3), 496-499; discussion 499-500.

5. Fabrizio Benedetti, Sergio Vighetti, Claudia Ricco và cộng sự (1998). Neurophysiologic assessment of nerve impairment in posterolateral and muscle-sparing thoracotomy. $J$ Thorac Cardiovasc Surg, 115(4), 841-847.

6. Kazuro Sugi, Sumihiko Nawata, Yoshikazu Kaneda và cộng sự (1996). Disadvantages of muscle-sparing thoracotomy in patients with lung cancer. World journal of surgery, 20(5), 551-555.

7. Yiğit Akçalı, Hasan Demir và Bekir Tezcan (2003). The effect of standard posterolateral versus Muscle-Sparing thoracotomy on multiple parameters. The Annals of Thoracic Surgery, 76(4), 1050-1054.

8. Stephen R. Hazelrigg, Rodney J. Landreneau, Thersa M. Boley và cộng sự (1991). The effect of muscle sparing versus standard posterolateral thoracotomy on pulmonary function muscle strength and postoperative pain. Thorac Cardiovasc Surg, 394-402.

9. E. Andrew Ochroch, Alan Gottschalk, John G. Augoustides và cộng sự (2005). Pain and Physical Function Are Similar Following Axillary, Muscle-Sparing vs Posterolateral Thoracotomy. Chest, 128(4), 2664-2670. 